\begin{tabular}{|c|c|}
\hline ANGLES & Angles \\
\hline $\begin{array}{l}\text { NEW PERSPELTWUE } \\
\text { ANGLOPHONE WORLD }\end{array}$ & New Perspectives on the Anglophone World \\
\hline & $\begin{array}{l}1 \mid 2015 \\
\text { Brevity is the soul of wit }\end{array}$ \\
\hline
\end{tabular}

\title{
Video introduction to issue 1
}

\section{Yan Brailowsky}

\section{(2) OpenEdition}

\section{Journals}

\section{Electronic version}

URL: https://journals.openedition.org/angles/1998

DOI: 10.4000/angles. 1998

ISSN: 2274-2042

\section{Publisher}

Société des Anglicistes de l'Enseignement Supérieur

\section{Electronic reference}

Yan Brailowsky, "Video introduction to issue 1", Angles [Online], 1 | 2015, Online since 01 November 2015, connection on 08 June 2022. URL: http://journals.openedition.org/angles/1998 ; DOI: https:// doi.org/10.4000/angles. 1998

This text was automatically generated on 8 June 2022.

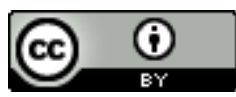

Angles est mise à disposition selon les termes de la Licence Creative Commons Attribution 4.0 International. 


\title{
Video introduction to issue 1
}

\author{
Yan Brailowsky
}

This media file cannot be displayed. Please refer to the online document http:// journals.openedition.org/angles/1998

\section{Transcript:}

Welcome to the first issue of Angles. My name is Yan Brailowsky, and I am this issue's guest editor.

2 The editorial committee thought that it would be a good idea to have a video introduction, rather than the usual written introduction, and so this is it. The choice of form is also one of substance: Angles wants to study the Anglophone world using different perspectives, different methodologies, taking risks, experimenting, even having fun. You might discover a surprise or two as you browse through the issue.

3 This issue's topic is inspired by the famous adage: 'Brevity is the soul of wit'. I hope that this section won't prove as dreary and repetitive as Ophelia's father. Nobody wants to end up stabbed, hiding in the queen's bedchamber.

4 The adage 'brevity is the soul of wit' is often used to describe humor or sarcasm. It suggests that true 'wit' exists only in shortened form, as if depth of meaning ('soul') required brevity of form. It also hints that humor loses its essence when explicated.

5 We start with two studies on $20^{\text {th }}$ century avant-garde poetry, poetry which aimed at trying to find the essence of language. The first contribution, by Yasna Bozhkova, focuses on Mina Loy, and locates her work in the utopian movements of the early $20^{\text {th }}$ century. This paper allows the reader to travel in time, from 1914 to 1945, from Paris and Florence to New York and Mexico, revisiting the poetic luminaries and revolutionaries of that period.

Axel Nesme chose a different approach to study Lorine Niedecker's poetry. He started with Freud's dictum that wit works through condensation and displacement, something which Niedecker defined as "condensery". Nesme's paper, which gives us a glimpse of the complexity of Niedecker's puns, also recalls the Post-War context in which she wrote, one in which people feared The Bomb. 
7 The Cold War required humor. A contribution by Raphaël Ricaud studies one example of humor used as stress relief, that of John Lackey Brown, a professional US diplomat. In this first stab at analyzing Brown's correspondence, Ricaud introduces the reader to the cultural cold War, and how diplomats could use wit to advance political causes.

After a graphic intermission, this issue offers other papers which study brevity and wit to reveal something about language itself. In a playful contribution, Jean-Jacques Lecercle takes an excerpt from Sam Selvon's The Lonely Londoners. Through a series of axioms and propositions, Lecercle not only gives us an primer on the wealth and wit afforded by New Englishes, he also makes serious points about the way language, through brevity and wit, questions us all, interpellates us.

Using a different material and approach, Shannon Wells-Lassagne also makes serious points when studying American sitcoms, from the early Dick Van Dyke Show to the Big Bang Theory. Sitcoms can be funny, but they also try to squeeze serious moral lessons between a couple of jokes, as shown in numerous extracts mentioned in the paper.

In some cases, the point of comedy is to prove that there is no point in making a point. This is what Thomas Britt shows in his paper on The Best Show on WFMU, a radio show in New Jersey. Britt analyses a famous sketch entitled "Rock, Rot and Rule". The sketch shows how the search for critical brevity can lead to chaos, a funny one at that, as Ronald Thomas Chontle, an imaginary author, tries to settle disputes between musical experts by devising a fool-proof method that is just that, foolish. You can listen to the audio clips with the reactions of listeners infuriated by Chontle's flawed rhetoric. If you've ever watched Fox News, you'll recognize some of Chontle's most obvious fallacies.

11 The last piece on Brevity and Wit offers a sort of typology of one-liners using linguistics. But hold on, this is linguistics made fun. In her paper, Catherine Chauvin takes different types of one-liners, ones based on puns, on ambiguous syntax, on setphrases, to show how central these examples are to key question in linguistics such as "default meaning(s), the role of context, and so on. You'll discover how many oneliners work, and you'll want to try a few examples on students and friends -for documentary purposes, of course.

12 Taken together, these contributions on 'brevity is the soul of wit' provide transhistorical and transcultural analyses, pointing out the formal and aesthetic aspects of certain forms, as well as the cultural and political use of jokes and repartee by writers, screen-writers, political commentators or politicians.

13 The journal has a second section, which has no topic. This issue's Varia contains three, very different, and really exciting contributions.

14 The first paper is an analysis of a parodic zombie movie, Shaun of the Dead, but the analysis is in comic-book form. Yes, that's right, a serious comic-book studying a parodic zombie movie. In this original contribution, Nicolas Labarre and Jean-François Baillon study the interplay between the romantic-comedy and the zombie film genres. You might also want to read Nicolas Labarre's reflections on the making-of, not of the movie, but the comic-book analysis. His blog provides the necessary background to understand why this contribution works better in this form than in any other, and provides food for thought for academics wishing to follow in his footsteps.

15 The second contribution is a video documentary, in which Mathilde Bertrand interviewed photographer Nigel Dickinson. Dickinson talks about his work covering a 
miners' strike at Lea Hall in the mid-1980s. The photographer recalls the context of the strike and how a mining community in Staffordshire used his photographs to tell their story their way. This was a welcome change to the way in which the media told the story for them-and no doubt a lesson for anyone today, such as low-wage Walmart employees, who need to tell the world their story in their terms.

The last contribution in this section is a study of a performance of Eugene O'Neill's The Emperor Jones by The Wooster Group. In this paper, Emeline Jouve uses Judith Butler's theories on performativity to see how the Wooster Group 'troubled' the notions of genre and race, by having Emperor Jones, a black man, played by a white woman... in blackface. Jouve's study shows how theater can effectively question the world, and perhaps bring about change.

17 I believe these three contributions in the Varia section pave the way for original research on pressing issues but research which can use new forms which make full use of the online format of this journal.

Other issues of Angles are already in the works, I'm happy to say, and you can find more information on the journal's website.

\section{ABSTRACTS}

This video begins by introducing the thematic contributions on the famous adage 'brevity is the soul of wit'. The eight contributions on the topic offer transhistorical and transcultural analyses which point out the formal and aesthetic aspects of certain forms, as well as the cultural context and political use of jokes and repartee by writers, screenwriters, political commentators or politicians. The guest editor then introduces the three contributions in the Varia section which give readers/viewers an inkling of the wealth of innovative research made possible by Angles and its online format.

La vidéo commence par présenter les contributions thématiques autour de l'adage «Brevity is the soul of wit » («puisque la brièveté est l'âme de l'esprit »). Les huit contributions proposent des analyses transhistoriques et transculturelles soulignant certains aspects formels et esthétiques de quelques formes, ainsi que le contexte culturel et l'usage politique qui peut être fait de jeux de mots ou de plaisanteries par des écrivains, des scénaristes, des commentateurs politiques ou des politiciens. Le responsable du numéro présente ensuite les trois contributions de la section Varia, car elles donnent un aperçu de la richesse et de l'innovation permises par Angles et son format numérique.

\section{INDEX}

Keywords: video, brevity, humour, wit, language, literature, history, film, experimental research Mots-clés: vidéo, brièveté, humour, langue, littérature, histoire, film, recherche expérimentale 


\section{AUTHOR}

\section{YAN BRAILOWSKY}

Editor-in-chief of Angles and Associate Professor at the University of Paris Ouest Nanterre La Défense. His research focuses on the early modern period. 